\title{
The Ottoman Turk in Maltese Theatre and Drama: A Discussion of the Role of Stereotypes in the Theatre of a Small Nation
}

\author{
Marco Galea ${ }^{1}$ (1)
}

Senior Lecturer, Department of Theatre Studies, School of Performing Arts, The University of Malta

ORCID: M.G. 0000-0001-8994-593X

Corresponding author / Sorumlu yazar: Marco Galea,

Senior Lecturer, Department of Theatre Studies, School of Performing Arts, The University of Malta, Malta

E-mail/E-posta: marco.galea@um.edu.mt

Submitted/Başvuru: 05.04.2021

Revision Requested/Revizyon Talebi:

19.04.2021

Last Revision Received/Son Revizyon:

19.04.2021

Accepted/Kabul: 25.05 .2021

\section{Citation/Atıf:}

Galea, Marco. "The Ottoman Turk in Maltese

Theatre and Drama: A Discussion of the Role

of Stereotypes in the Theatre of a Small Nation"

Tiyatro Eleştirmenliği ve Dramaturji Bölümü Dergisi

32, (2021): 23-36

https://doi.org/10.26650/jtcd.909750

\section{ABSTRACT}

The aim of this article is to discuss how the theatre of a community aspiring to nationhood and autonomy from British colonial rule used stereotypes inherited from popular history and nationalist discourse to create drama that contributed to shaping a national identity. The article will also discuss how these stereotypes were retained within the Maltese performative culture beyond the political realities that ushered them in. To do this, the article analyses the references to Ottoman Turks in Maltese theatre from the $19^{\text {th }}$ century to the contemporary period. Most of these instances revolve around the Siege of Malta of 1565 by the Ottoman army, which is considered a moment of great importance in the history of the country. In these works, as in Maltese culture in general, the Turk is seen as the nemesis of the Maltese and represents everything they are not. The article contextualises the different recorded performances in the historical moment they speak of, but also in the historical moment they were enacted. The discussion is framed around colonialism as a historical period and as a theoretical concept which informed the Maltese national identity.

Keywords: Maltese theatre, 1565 Siege of Malta, British colonialism, Ottomans, Race 
Malta is a small island state in the central Mediterranean. With a population of around half a million people, it is one of the smallest states in the European Union. Having been an independent country since 1964, it has developed into a relatively successful economy, due largely to a thriving tourist industry which besides the climate and beaches, has exploited the country's rich history. However, Malta would be a very different place, and probably not even a country if it were not for its relationship with the Ottoman Empire. This relationship has also been an important building block for Maltese national identity and culture. ${ }^{1}$

Malta (and its smaller, dependent, islands) has had a long history of colonisation. Being in a strategic position roughly equidistant between the southern coasts of the European continent and the northern shores of the African continent and having convenient natural harbours, it attracted the attention of any power that wanted to dominate the Mediterranean or at least control its trade routes. Most of the important historical Mediterranean powers ruled over the island. This meant that Malta was part of the Phoenician trade route, ${ }^{2}$ an outpost of the Roman empire and then of the Byzantine empire, a less important colony during the Muslim expansion into Europe, ${ }^{3}$ and for centuries a fief to many of the smaller powers that came out of Europe in the late Middle Ages. All of these colonisers left an imprint on the island. For example, Maltese, the language spoken to this day in the country, is a direct descendent of an Arabic dialect introduced to the island by colonisers from the Maghreb region after the $9^{\text {th }}$ century, ${ }^{4}$ and is the only national language of Semitic origins in Europe.

However, Malta acquired a political importance that belied its size from 1530 when the Order of St John accepted to make the island its home after losing Rhodes to the Ottomans. The event which consolidated the connection between the Order and the island of Malta was what in Malta is still known as "The Great Siege" of 1565. As part of a larger project to acquire a foothold in Western Europe, an Ottoman army invaded Malta in the summer of 1565. Accounts of the siege state that the Ottoman invading army was made up of about 65,000 trained soldiers, while the island was defended by a garrison of about 500 knights and 2,000 mainly untrained Maltese fighters. ${ }^{5}$ Given that the Order had only taken control of the island 25 years earlier and was initially unconvinced that the island was suited for their mission to protect the pilgrims en route to the Holy Land, the island had to rely on inadequate and outdated fortifications. Therefore, it is easy to understand why many narratives of the siege given by the knights of the Order of St John and by Maltese writers see this as a David vs Goliath encounter, with the locals, against all odds, defeating a much stronger opponent. The

Carmel Cassar, Society, Culture and Identity in Early Modern Malta (Malta: Mireva, 2000), 228-234.

Anthony Bonanno, Malta: Phoenician, Punic, and Roman (Malta: Midsea Books, 2005), 20-22.

Charles Dalli, Malta: The Medieval Millennium (Malta: Midsea Books, 2006), 57-59.

Joseph M. Brincat, Maltese and Other Languages: A Linguistic History of Malta (Malta: Midsea Books, 2011), 44-49.

5 A detailed account of the planning and the execution of the siege, relying on sources in the Istanbul State Archives can be found in Arnold Cassola, The 1565 Ottoman Malta Campaign Register (Malta: PEG, 1998). 
failure of the Ottoman army to take Malta was seen as a highly significant moment for Western European powers, and by extension, for the survival of Christianity in Europe. ${ }^{6}$ It also marked a change in attitude by the Order towards Malta, whereby they became convinced that their future was on the island and they therefore embarked on building a new fortified city, and creating the infrastructure to live safely and comfortably there. Put simply, during the century and a half of the Order's rule over Malta, the island became an autonomous state, although the native population had very little influence on the way it was governed. With time the siege acquired legendary status, with paintings being commissioned to commemorate it and books written about it. It was used by the Order to affirm its authority over the island, also when the Ottoman threat was no longer real.

To this end, the Order incorporated narratives of the Great Siege into open-air public performances that were meant for consumption by the native population which was generally excluded from performances in formal theatres. During the $18^{\text {th }}$ century, every year, for the celebration of spring, a musical performance was commissioned to commemorate the Order of St John's greatest achievements and to laud the current grandmaster. The texts for these performances often referred to the 1565 siege, and at least two, La Pietà Coronata (The Crowning of Mercy, 1750) and I trionfi di Malta sui nemici della fede (Malta's Triumph over the Enemies of the Faith, 1755) made it their central plot. ${ }^{7}$

Although the relationship between the Order and the Maltese was often problematic, the latter generally accepted the narrative of the Great Siege as the most glorious moment in the island's history. An almost continuous performance tradition which goes back to at least the $18^{\text {th }}$ century is that of the carnival parata. This is a sword dance that is performed every year as a signal for the carnival celebrations to start. The performers dress up as knights and Ottoman fighters and re-enact a generic battle from the Great Siege, where invariably the knights win. A description from the early $20^{\text {th }}$ century refers to the two groups of dancers as "Christains" and "Turks", 8 an obvious reference to the binary opposition that had been accepted between the Christian Maltese and the Muslim Ottomans. During the rule of the Order of St John and during British rule (1800-1964), the parata had to be authorised by the authorities, and was also subsidised. There are even contracts from the $18^{\text {th }}$ century stipulating the conditions under which the performers were to participate. It is thus evident that the Great Siege was central to official discourse about identity.

6 Thomas Freller, Malta: The Order of St John (Malta: Midsea Books, 2010), 99.

7 Joseph Eynaud, "Teatro e folcolore a Malta nel secolo decimottavo," Melita Historica 6/2 (1973), 161.

8 Sibella Bonham-Carter, “The Maltese Parata: A Men's Sword Dance”, Journal of the English Folk Dance and Song Society 5/1 (1946), 66; quoting Anthony Cremona, a Maltese folklorist. See also Cassar, Society, Culture and Identity in Early Modern Malta, 234. 
Identity became a more contested issue during the $19^{\text {th }}$ century. A number of factors ${ }^{9}$ had fostered the concept that the Maltese had the characteristics required to be able to claim that they were a distinct nation, occupying a clearly defined territory, using a language that distinguishes them from any other nationality, and sharing a common history and religious heritage. These qualities became particularly important in the light of British colonial policy that negated agency to all indigenous populations and fostered an ideology that attributed very little value to cultures that were considered different to major European ones, or to communities which expressed themselves through these cultural markers. In Malta, this colonialist attitude manifested itself through attempts to introduce the English language into education, justice and administration, as well as introducing legislation and policies which made adopting the culture of the colonisers a prerequisite to being considered for most positions in public life.

It was in this context that a renaissance of popular culture took place from the early $19^{\text {th }}$ century. For the first time a number of intellectuals and artists started using Maltese as a language of artistic expression, while until then, the language of culture had been Italian. Anyone who wrote poems or texts for theatre would have written in Italian. The Maltese language, previously limited to oral communication, now became a symbol of this renaissance, and a statement of the democratic intentions of these writers, as Italian was understood only by the upper classes, while Maltese was the language spoken by everyone, even if it had no literary tradition. Much of this writing is rich in political content, and generally political, religious and linguistic arguments came together to create a body of works that is romantic in inspiration, but mainly focused on the issue of national identity. Many of the early poetry written in Maltese speaks of the beauty of the Maltese islands, the qualities of the Maltese people, perceived as an honest, courageous, and God-fearing population, ${ }^{10}$ and often refers to history to substantiate its arguments. A case in point is Ġan Anton Vassallo's Il-Gifen Tork (The Turkish Warship), a long poem written in 1842. It narrates, with a fair amount of poetic licence, a historical event that took place in 1760, when a number of Maltese slaves managed to capture the Corona Ottomana, the ship they were held on as rowers, and steered it to Malta, where they regained their personal freedom and handed the ship over to the Order of St John. The poem stops with the triumphant pilgrimage that the Christian slaves made to a well-known sanctuary in Malta. ${ }^{11}$ Many other poems, including some of the national poet

9 These factors include influences from the Romantic Movement which had swept Europe in the late $18^{\text {th }}$ century and the early $19^{\text {th }}$ century, the presence of Italian risorgimentisti in Malta, the birth of a free press on the island and the gradual introduction of free public schooling.

10 A good example of this type of poetry is that written by Ġan Anton Vassallo, see also Gio Antonio Vassallo, Il-Poeziji (Malta: Malta University Press, 2012).

11 For a detailed analysis of this poem see Marco Galea, "Renewing an Enemy-Ship: Turk sightings in nineteenth century Maltese literature”, Sacra Militia 4 (2006), pp. 29-34. https:/www.academia.edu/45664208/Renewing an_Enemy_ship_Turk_sightings_in_nineteenth_century_Maltese_literature. 
(Dun Karm Psaila)'s better known works, deal with the events of the Great Siege. ${ }^{12}$ However, before all this had happened, it was theatre that set the tone for the way art would depict the Maltese/Ottoman relationship. And it is perhaps no coincidence that the first original play in Maltese that we know of is based on the 1565 siege. The play was called Katarina and it was written by Luigi Rosato.

Rosato was a singer employed on a part-time basis ${ }^{13}$ with the main theatre in Malta when in 1839 he wrote the play to be performed on his benefit night. The Real Teatro was owned and controlled by the state, which even during the British colonial period saw it primarily as an opera theatre and appointed an impresario to hire an opera company and organise the programme for one or more seasons. What spectators watched at this theatre was therefore mainly Italian opera, as English theatrical genres had made very little inroads on the island. Thus, when Rosato decided to write a play in Maltese and perform it for a public accustomed to watch performances only in Italian, he was making a strong political statement in favour of a new culture that used the vernacular language as its primary means of expression. The subject matter is also very significant. By choosing to write about the Great Siege, Rosato is highlighting the issue of nationality and using history to highlight the values that he (and most intellectuals of his time) considered to be markers of Maltese national identity. The Maltese are depicted as brave, honest and faithful to their religion. All these are characteristics which were important for the nation-building project that artists were slowly embarking on, and which would before long be taken up by the first generation of politicians fighting for rights and representation from the colonial government.

The play, written in verse, dramatizes the story of a young Maltese woman and her family, who are caught up in the events of the siege of 1565 . The first part of the play is very narrative in nature. It immediately sets out the parameters within which it is discussing the siege. In the worldview created by the play this is a war between good and evil, between an innocent community and an aggressive invader, between Christianity and Islam. The Ottomans, or as they are invariably referred to in the play, Turk/s, are described in negative, even demeaning, terms. They are "cursed" and "cruel" and their character and intentions are reflected even in their physical appearance:

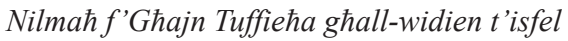

Qatta Torok jigru mal-plajja kollha.

12 See as examples Dun Karm Psaila, "Il-Ghanja tar-Rebћa” (The Song of Victory), "Dehra tat-VIII ta' Settembru 1565" (A Vision of $8^{\text {th }}$ September 1565) in Il-Poeziji Migbura (Malta: Klabb Kotba Maltin, 1980) 190-2, 202.

13 Due to the size of the country and lack of investment in the performing arts, most performing artists in Malta are either amateur or can only work as performers on a part-time basis. See Vicki Ann Cremona and Marco Galea, "The Amateur Theatre in Malta," Amfiteater 8/1 (2020), 196208. https://www.slogi.si/wp-content/uploads/2020/07/Amfiteater-8_1_RAZ_07_Cremona_Galea_ AN.pdf?fbclid=IwAR0NnyrnglTfphafz5A9CPb1aIGa5YAhrFylyffUOdLNHp $\overline{\text { 9 }}$ XMĀphm6UHP8. 
X'erba'mitt ruh, Gannizzari u Sanġakki,

Dak l-ilbies taghhom jilma,

Dawk it-tghanijiet ilellxu f'idejhom,

Dik il-kruha ta' wic̀chom

Gaghluni neћmed fejn kont.

In the valleys of Ghajn Tuffieha (a beach towards the north of the island)

I saw a throng of Turks along the beach.

Around four hundred of them, Janissaries and flag-bearers,

Their uniforms shining,

The scimitars in their hands catching the light,

The ugliness of their faces

Made me stop in my tracks. ${ }^{14}$

Several people who have witnessed battles come on stage to inform the other characters of what is happening. Their narratives are full of tales of plundering and violence from the Ottoman side, and courageous resistance by the Maltese and their overseers. The overriding sentiment is one of mutual hate between the two opposing forces. Particular attention is given to the Ottoman general, Dragut (Turgut Reis), whose exploits as military leader and corsair created fear in all southern European leaders. Dragut had previous history with the Maltese and the Order, as he had attempted to invade the islands several times in previous decades, and had managed to conquer the dependant smaller island of Gozo, taking all its able-bodied inhabitants as slaves. He had also, on several occasions, plundered ships belonging to the Order of St John. ${ }^{15}$ In the play he is described as an enemy of the Maltese, who has sworn to annihilate them, and who must therefore be killed. However, among the Maltese characters in the play, fear of Dragut and of his soldiers paralyse them.

All this sets up the play for its climax. Katarina, the character which gives the play its name but who until the last scene had been primarily passive is suddenly thrust into the midst of the action. An Ottoman general who is conveniently named Assan sets eyes on Katarina and would like to possess her. As spectators we had been warned about him in the previous scene, when he had been introduced through a monologue in which he vents his hatred against the islanders and instructs his soldiers to butcher the Maltese, and not show any mercy to anyone. He is motivated by his conviction that all Christians are evil and by his loyalty to Suleyman the Magnificent who had ordered the siege and whose great wish it was to conquer Malta, as

14 Luigi Rosato, "Katarina," in Marco Galea (ed.), It-Teatru Malti tas-Seklu Dsatax I (Maltese Theatre in the Nineteenth Century) (Malta: Mireva Publications, 1997) 6. Translations from the Maltese are by the present author.

15 Corsairing was an accepted activity in the Mediterranean until the late $18^{\text {th }}$ century, which different states regulated through licencing and taxing. Grandmaster La Valette, who ruled over the Order of St John and as a consequence over Malta during the siege of 1565, was himself reputed to be a very good corsair. See Liam Gauci, In the Name of the Prince: Maltese Corsairs 1760-1798 (Malta: Heritage Malta, 2016). 
the Order of St John had been disrupting the Ottomans through their corsairing. Besides being depicted as blood-thirsty and lacking any mercy, Assan is also described in racial terms. The only physical detail that the playwright feels he needs to give us is that Assan is black. The issue of blackness is often encountered in $19^{\text {th }}$ century and early $20^{\text {th }}$ century Maltese fiction and drama. Although racial difference is present in a lot of European writing of the period, as a result of colonial perceptions and local resistance to them, in Maltese writing it is more accentuated.

Colonial attitudes to race were fairly uniform. European colonialists saw themselves as racially superior to any racial community they subdued. Science was roped in to explain racial differences and extrapolate that white Europeans were racially superior. In fact, the colonial project was often referred to as the "white man's burden" from a phrase used in a Rudyard Kipling poem. This pseudo-scientific hierarchy of races ${ }^{16}$ was used to justify the inhumane treatment often used against indigenous populations within the colonial context. To quote Albert Memmi:

The European colonists, as the dominant group, literally had to be racist to legitimize their control. To continue to live as colonists, to which all alternative had already become unimaginable for them, they had to render inferior their ill-fated partners in the colonial relation. ${ }^{17}$

As a result, colonised communities tried to work their way around this discrimination. As Fanon had already noticed in Black Skin, White Masks, the classification of colonised races according to how close or far in complexion they were to their colonisers led to granting some rights to one group but not to another. ${ }^{18}$ Thus for the colonised subject (and by extension the colonised community) to survive within the colonial system, it was imperative to place themselves as close as possible in racial terms to their colonial rulers, and this could only be done by distancing themselves from other colonised communities. Fanon gives an example of how people from the Antilles distanced themselves from Senegalese people because they felt the latter were darker than themselves. ${ }^{19}$ In the Maltese context, the indigenous population, or at least those amongst the population who had a European education, refused to be labelled nonwhites and non-Europeans as they were considered by their British rulers, and in the context of the colonial world, they felt that the only way to do this was to emphasise their superiority over other colonised peoples. Politicians regularly claimed that culturally and racially, the

16 See John P. Jackson Jr and Nadine M. Weidman, Race, Racism and Science (Santa Barbara: ABC-Clio, Inc, 2004), 44-57.

17 Albert Memmi, Racism (Minneapolis: Minnesota University Press, 2000), 31.

18 Linda Lane and Hauwa Mahdi, "Fanon Revisited: Race Gender and Coloniality Vis-à-Vis Skin Colour," in R.E. Hall (ed.) The Melanin Millennium: Skin Color as 21 st Century International Discourse (Dordrecht: Springer), 170-171.

19 Frantz Fanon, Black Skin, White Masks (London: Pluto Press, 2008), 14-5. 
Maltese were much closer to Europe than they were to Africa. ${ }^{20}$ In popular culture, Africa was the land of the blacks, and anything to the south of Malta was Black Africa. This "other" world included Turkey, or at least the Turkey of the Great Siege. In Maltese consciousness, the Turk was, and to some extent still is, perceived as being black. Given the problematic role that race has played in the creation of modern Turkey, ${ }^{21}$ the uninformed and derogative appellation is ironic. From a Maltese point of view it is also unforgivable as during the $17^{\text {th }}$ century Malta was in constant contact with ethnic Turks, who were enslaved in Malta in their hundreds. ${ }^{22}$ In fact the most widely used Maltese-English dictionary, after recording the phrase "iswed Tork" gives this explanation "(lit.) as black as a Turk (here the word Turk is misused for Moor or Berber who, unlike the Turks, are dark skinned." ${ }^{23}$ The same dictionary records a phrase describing an unbaptised baby as "ghadu Tork" (being still a Turk), ${ }^{24}$ which further emphasises the dichotomy whereby in Maltese minds being Maltese stood for being good, white, beautiful and Christian, while being Turk meant the exact opposite: evil, black, ugly and Muslim.

Therefore, when Katarina is repulsed by the Turk's advances in the play, it is not only or mainly the issue of sexual violence that is at play. Katarina is repulsed as any type of closeness with Turks is against her nature. As Assan offers her his wealth in exchange for her acceptance to be his partner, she prays to God to keep her strong in order to protect her virtue and her island, and addresses her nemesis:

\section{Ragel ahrax tbieghed minni,

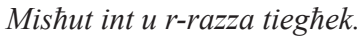 \\ Lesti qabar, fih idfinni

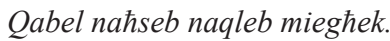

\section{Move away from me, cruel man, \\ Cursed are you and your race. \\ I'd rather you dug a grave and buried me \\ Than consider joining you. ${ }^{25}$}

Being the villian that he is in the play, he of course kills her immediately. Beyond the point that the play wants to make that the virgin's sacrifice will allow the community to overcome its inertia, there is the underlying issue of the fear of miscegenation that is at play here. In fact, racial purity would become an objective tied to national identity, claimed to be true by

20 Geoffrey Hall, The Maltese Language Question (Malta: Said International, 1993), 122, 273.

21 Murat Ergin “'Is the Turk a White Man?' Towards a Theoretical Framework for Race in the Making of Turkishness,” Middle Eastern Studies 44/6 (2008), 827-850.

22 Godfrey Wettinger, Slavery in the Islands of Malta and Gozo ca. 1000-1812 (Malta: PEG, 2002) 36-39.

23 Joseph Aquilina, Maltese English Dictionary II (Malta: Midsea Books, 1990), 1466.

24 Ibid.

25 Rosato, Katarina 25-6. The last verb as used in Maltese refers both to getting close to the male and to apostasy. 
politicians and celebrated by writers. Again, using racial purity as a marker of identity was a concept that was given currency by colonialists, especially in the light of theories that claimed that different races had separate origins.

The importance of the play lies not only in the fact that it is the first play in the Maltese language known to have been performed, but also in that it set the tone for much of what was written during the $19^{\text {th }}$ and early $20^{\text {th }}$ century. An author who is acknowledged as "the father of Maltese literature", Ġużè Muscat Azzopardi, wrote a series of short historical novels, most of which focus around the 1565 siege. These novels try to contribute to the nation-building process by foregrounding the eternal battle between the Maltese and the Turk, and in many of these novels, the defeated Turkish villains are punished in an almost sadistic way, to give a warning that whoever crosses the Maltese would pay. In these novels Turks are always portrayed as black, and their skin colour is associated with dirt. In order to infiltrate the Ottoman camp during the siege, one Maltese hero has to paint his face using burnt cork. ${ }^{26}$ These novels were widely read and remain in print to this day. The pseudo-historic exploits of the Maltese heroes depicted in them acquired legendary status and towards the end of the $19^{\text {th }}$ century they were often adapted into stage plays, ${ }^{27}$ and were possibly the main source of historical information for large numbers of illiterate or semi-literate spectators. These adaptations were mostly made by insignificant theatre-makers, but were hugely popular around the turn of the $20^{\text {th }}$ century. For example, in 1894, the most important theatre company of the time, L'Indipendenza, performed a series of historical plays, with some titles indicating that they were in fact adaptations from Muscat Azzopardi. After a run at an out-of-town theatre that was mostly patronised by villagers, the plays were performed again successfully at the more important Manoel Theatre in Valletta, presumably to a more urban audience. ${ }^{28}$ The texts for most of these adaptations have not survived, but we know that they were very similar to the novels they were adapted from. It is therefore safe to assume that the portrayal of the Ottoman Turk as the other that we encounter in the novels was retained in these adaptations. Such an adaptation, from 1930, has survived and points in the same direction. Very little is known about this text besides its date. The author is not mentioned and we know it was probably performed because a version of the text includes handwritten directorial notes. ${ }^{29}$ This text is called Il-Ballata ta' Toni Bajada (The Ballad of Toni Bajada) and is clearly based on Muscat Azzopardi's novel Toni Bajada. Not only are the characters identical in name and behaviour, but many of the situations are also lifted from the novel. The play focuses on the eponymous character, who is portrayed in

26 Gużè Muscat Azzopardi, Toni Bajada u rakkonti ohra (Toni Bajada and other narratives) (Malta: KKM, 1977), 31.

27 Anon. Il-Gahan tas-Soltu. 22 September 1906, 4.

28 M.A. Borg, Gheluq il-Hamsin Sena (Malta: Tipografia Nazionale), 32-3.

29 Two versions of the text exist, preserved in digital format by the School of Performing Arts' Digital Archive (University of Malta) . They were typed using the same typewriter and quality of paper. One of them is dated 1930 but it is clear they are from the same period (https://www.um.edu.mt/library/oar/handle/123456789/40121. Accessed 28 April 2021). 
almost superhuman terms. For example, with very little experience, he can single-handedly steer a sailing ship through a terrible storm, and even manages to escape from slavery and make his return to Malta. One of his defining characteristics is his hatred for Turks, who he describes more than once as "unbaptized dogs". He has a fixed idea of what it means to be a Maltese and a Christian, and for him, being a Turk precludes anyone from becoming Maltese. This is best exemplified in the play by his encounter with Hamid Zuta, an Ottoman corsair he leaves to drown after sinking his ship, ${ }^{30}$ but who ends up in Malta as a slave, converts to Christianity and is employed by Toni's family in his absence. Yet Toni's theory that you can never trust a Turk, even if he clearly shows you that he is a friend and ally: "Min jitghammed bis-snien, jitghammed taparsi... jien ma nafdah xejn... kulhadd merqtu u ftietu" (Whoever is baptized after his teeth have grown, is baptized only in name... I don't trust him... I will have nothing to do with him) $)^{31}$ is eventually proved right. As soon as the Ottoman invading army landed in Malta in 1565, he openly joined their ranks, confident that their military superiority would prove too much for the Maltese and he could pay the latter back for enslaving him. This betrayal of the Maltese interests therefore leads to his being condemned to die by hanging, and the execution is not only public but within the drama is juxtaposed with the representation of Toni's wedding to his beloved.

It is perhaps not a coincidence that one of the very few plays about the Great Siege to have survived is from 1930. During the previous decade, the Maltese had acquired self-government and had the first truly representative parliament, albeit with limited powers. During this time, the narrative of the Great Siege victory was pushed to the forefront, with an important monument erected in one of the main squares of Valletta in $1927,{ }^{32}$ and in the same year an annual tradition (which is still ongoing) was initiated by commissioning Dun Karm, the national poet to write a speech to commemorate the event. A poem ${ }^{33}$ he wrote as a conclusion to his speech includes all the stereotypes that we encounter in the fiction and drama about the siege during the whole period leading up to independence. The Maltese are portrayed as brave and perseverant, and fighting for what was right, while the Turks are shown as cruel and pertaining to the "wrong" religion. The poem, like the other works discussed here, needs to be read in the context of a nation still in its infancy, whose population needs to be reassured that their battles are worth fighting, and that there were moments in the past which highlighted the values they needed to cultivate to acquire a national identity that could stand its own within the context of colonialism and the struggle for autonomy. In this light, the Turk came to represent everything the Maltese were not (or aspired not to be), the Other against whose image what being Maltese meant could be seen more clearly.

30 Anon., Il-Ballata ta' Toni Bajada, 6.

31 Il-Ballata ta' Toni Bajada, 18.

32 Wikipedia, 'Great Seige Monument', https://en.wikipedia.org/wiki/Great_Siege_Monument. Accessed 29 April 2021.

33 The title of the poem is 'L-Ghanja tar-Rebha' (The Song of Victory). 
After Independence, which Malta acquired in 1964, historical drama was no longer a politically useful genre in Malta, and there have therefore been fewer opportunities for the portrayal of Turkish characters from the past in mainstream theatre. However, given that the Great Siege is considered to "represent a very crucial episode that contributed towards the creation of a Maltese identity, both in fact and in concept," 34 these events are regularly commemorated through pageantry, such as in historical re-enactments. Besides this, celebratory performances sometimes rework this story for large scale shows. An opera, The Maltese Cross was performed in 1995, and a musical entitled 1565 The Musical premiered in 2005, to be revived in a revised version in 2015. In 2006, a performance aimed at the tourist market, Knights Spectacular 1565, started a run that lasted several years. The latter two productions rely on stereotypical characterisations for their Turkish characters, not too differently from what had been done for the 1839 play we discussed earlier. Even sexual violence is used as a marker for the Ottoman soldiers in 1565 The Musical. ${ }^{35}$

The Turk is also a frequent presence in comedy. In a 1908 adaptation of Georges Feydeau's La Dame de Chez Maxime, a ghost of an Ottoman soldier is introduced for comic effects. ${ }^{36} \mathrm{In}$ fact, Turkish soldiers from the Great Siege still seem to resonate with comedy audiences. A 2012 grotesque retelling of the history of the city of Valletta included as its main character Dragut (Turgut Reis), a ghost who haunts the city where he died. ${ }^{37}$ As recently as 2018, a Christmas pantomime entitled La Valette $u$ t-Tliet Muscatieri (La Valette and the Three Musketeers) retold the 1565 siege where both the Maltese and the Turks are unworthy fighters, but the jokes are mostly on the Turks. ${ }^{38}$

The Maltese population is constantly reminded of the 1565 siege. The event is commemorated every year on the $8^{\text {th }}$ September, which is a national holiday, aptly known as Victory Day. It is commemorated by traditional boat races and a speech by a public figure next to a monument marking the siege. History curricula at all levels emphasise the siege and the time of the Order of St John, and it is often referenced in mundane objects such as adverts and commemorated through beers and wines. It is not an exaggeration to claim that in the Maltese national consciousness, the 1565 siege, perhaps along with World War II, is much more significant even than the acquisition of independence.

In recent years, the 1565 siege has inspired performances in a most improbable field. In 2007 the Maltese national football team was drawn to play against Turkey in the qualifying

34 Cassar, Society, Culture and Identity in Early Modern Malta, 235.

35 Paul Xuereb, “The Great Siege in a Minor Mode," The Sunday Times of Malta 20 February 2005.

36 M.A. Borg, 'Żeża tal-Flagship' in Opere in Vernacolo II (Malta: Tipografia Nazionale, 1930), 7-8.

37 Trevor Żahra, Xaghriet Mewwija (Sheltered Plains), unpublished playtext, 2012. Performed in 2018: Accessed 29 April 2021, https:/www.kreattivita.org/event/xaghret-mewwija-2/.

38 For a discussion on the Maltese version of British Christmas pantomime, see Marco Galea, "The Pantomime Other: Building Fences in Pantomime Performance in Malta", Otherness: Essays and Studies 5/1 (2016), 113130 . 
group for the European championship. By coincidence, the home match was to be played on the $8^{\text {th }}$ September. Local supporters grabbed the opportunity to organise themselves. They used the historical coincidence to drum up support for the national team. In the weeks leading up to the match, billboards appeared in various parts of the island advertising the match and the supporters' union, using iconography associated with the siege, mainly a knight's armour with a football in place of a human head. ${ }^{39}$ Videos were posted on YouTube making direct links between the siege and the match, ${ }^{40}$ and on the day hundreds of supporters turned up at the stadium dressed up as knights or wearing the Knights' eight-pointed cross on black t-shirts. Even though historically Maltese persons were not allowed to become members of the Order of St John, the supporters of the national football team have adopted the iconography of the knights to represent them. After the Malta-Turkey match (which ended in a draw, the best result Malta had ever obtained against that opposition), the supporters retained the iconography and choreography related to the siege. Knights in armour and the eight-pointed cross feature regularly in their communication, ${ }^{41}$ and this kind of choreography has split into the support for the national teams in other disciplines, such as rugby and water polo.

Today, it would be ridiculous to say that there are any remains of the enmity that characterised the relationship between Malta and Turkey from the $16^{\text {th }}$ to the $18^{\text {th }}$ centuries in political terms. The two countries enjoy good political and economic relations. However, the narrative that developed through the centuries and was reinforced during the $19^{\text {th }}$ century, at a crucial formative period for the creation of a Maltese national identity, is very difficult to dislodge. It is embedded in a culture, a literature and a language. Almost sixty years after the end of formal colonialism in Malta, a frame of mind that was created as a consequence of colonial rule is still very strong. Its manifestations in sport may seem light-hearted, but when it manifests itself as xenophobia and a reluctance to accept outsiders into the community, especially if they come from what is perceived as the south, it becomes problematic. Of course, none of the animosity is addressed towards Turks, but it is addressed towards people who correspond to the Maltese historical definition of the Turk.

39 Herman Grech, "Turkish fans may take no delight in Malta clash," Times of Malta 24 August 2007: Accessed 2 April 2021.https:/timesofmalta.com/articles/view/turkish-fans-may-take-no-delight-in-malta-clash.7159.

40 Grandmeme, "Malta vs Turkey - South End Core,"YouTube: Accessed 2 April 2021 https://www.youtube.com/ watch?v=61br13ZgYCg.

41 Publicity artwork for England vs Malta football match 2016: Accessed 2 April 2021. https://www.facebook. com/photo?fbid=10210568993242221\&set=gm.10153894546597555. 
Peer-review: Externally peer-reviewed.

Conflict of Interest: The author has no conflict of interest to declare.

Grant Support: The author declared that this study has received no financial support.

Hakem Değerlendirmesi: Dış bağımsız.

Çıkar Çatışması: Yazar çıkar çatışması bildirmemiştir.

Finansal Destek: Yazar bu çalıșma için finansal destek almadığını beyan etmiștir.

\section{BIBLIOGRAPHY / KAYNAKÇA}

Anon. Il-Gahan tas-Soltu. 22 September 1906.

Anon. Il-Ballata ta'Toni Bajada (unpublished playtext) 1930. Accessed 29 April 2021, https://www.um.edu. mt/library/oar/handle/123456789/40121.

Aquilina, Joseph. Maltese English Dictionary II. Malta: Midsea Books, 1990.

Anthony Bonanno, Malta: Phoenician, Punic, and Roman. Malta: Midsea Books, 2005.

Bonham-Carter, Sibella. "The Maltese Parata: A Men's Sword Dance," Journal of the English Folk Dance and Song Society 5/1 (1946), 65-67.

Borg, M.A. Teatro in Vernacolo II. Malta: Tipografia Nazionale, 1930.

Brincat, Joseph M. Maltese and Other Languages: A Linguistic History of Malta. Malta: Midsea Books, 2011.

Cassar, Carmel. Society, Culture and Identity in Early Modern Malta. Malta: Mireva, 2000.

Cassola, Arnold. The 1565 Ottoman Malta Campaign Register. Malta: PEG, 1998.

Cremona, Vicki Ann and Marco Galea, "The Amateur Theatre in Malta," Amfiteater 8/1 (2020), 196-208,https://www.slogi.si/wp-content/uploads/2020/07/Amfiteater-8_1_RAZ_07_Cremona_Galea_ AN.pdf?fbclid=IwAR0NnyrnglTfphafz5A9CPb1aIGa5YAhrFy1yffUOdLNHp9cXMAphm6UHP8.

Dalli, Charles. Malta: The Medieval Millennium. Malta: Midsea Books, 2006.

Ergin, Murat. “'Is the Turk a White Man?' Towards a Theoretical Framework for Race in the Making of Turkishness", Middle Eastern Studies, 2008, 44/6, 827-850.

Eynaud, Joseph. “Teatro e folcolore a Malta nel secolo decimottavo,” Melita Historica 6/2 (1973), 153-161.

Fanon, Frantz. Black Skin, White Masks. London: Pluto Press, 2008.

Freller, Thomas. Malta: The Order of St John. Malta: Midsea Books, 2010.

Galea, Marco. "Renewing an Enemy-Ship: Turk sightings in nineteenth century Maltese literature", Sacra Militia 4 (2006), 29-34, https://www.academia.edu/45664208/Renewing_an_Enemy_ship_Turk_ sightings_in_nineteenth_century_Maltese_literature.

Galea, Marco. "The Pantomime Other: Building Fences in Pantomime Performance in Malta", Otherness: Essays and Studies 5/1 (2016), 113-130.

Gauci, Liam. In the Name of the Prince: Maltese Corsairs 1760-1798. Malta: Heritage Malta, 2016.

Grandmeme, "Malta vs Turkey - South End Core," YouTube, Accessed 2 April 2021, https://www.youtube. $\mathrm{com} /$ watch? $\mathrm{v}=61 \mathrm{br} 13 \mathrm{ZgYCg}$. 
Grech, Herman. "Turkish fans may take no delight in Malta clash," Times of Malta, 24 August 2007, Accessed 2 April 2021, https://timesofmalta.com/articles/view/turkish-fans-may-take-no-delight-inmalta-clash.7159.

Hall, Geoffrey. The Maltese Language Question. Malta: Said International, 1993.

Jackson, John P. Jr and Nadine M. Weidman, Race, Racism and Science. Santa Barbara: ABC-Clio, Inc, 2004.

Lane, Linda and Hauwa Mahdi, "Fanon Revisited: Race Gender and Coloniality Vis-à-Vis Skin Colour," in R.E. Hall (ed.) The Melanin Millennium: Skin Color as 21st Century International Discourse. Dordrecht: Springer, 2004.

Memmi, Albert. Racism. Minneapolis: Minnesota University Press, 2000.

Muscat Azzopardi, Gużè. Toni Bajada u rakkonti oћra (Toni Bajada and other narratives). Malta: KKM, 1977.

Psaila, Dun Karm. Il-Poeżiji Migbura. Malta: Klabb Kotba Maltin, 1980.

Rosato, Luigi. "Katarina," in Marco Galea (ed.), It-Teatru Malti tas-Seklu Dsatax I (Maltese Theatre in the Nineteenth Century) (Malta: Mireva Publications, 1997) 1-27.

Vassallo, Gio Antonio. Il-Poeżiji. Malta: Malta University Press, 2012.

Wettinger, Godfrey. Slavery in the Islands of Malta and Gozo ca. 1000-1812. Malta: PEG, 2002.

Wikipedia, 'Great Siege Monument', Accessed 29 April 2021, https://en.wikipedia.org/wiki/Great_Siege_ Monument.

Xuereb, Paul. "The Great Siege in a Minor Mode," The Sunday Times of Malta, 20 February 2005.

Żahra, Trevor. Xaghriet Mewwija. Unpublished playtext, 2012. 